\title{
GENETIC DIVERSITY IN COMMON BEAN ACCESSIONS EVALUATED BY MEANS OF MORPHO-AGRONOMICAL AND RAPD DATA
}

\author{
Alisson Fernando Chiorato ${ }^{1}$; Sérgio Augusto Morais Carbonell ${ }^{1 *}$; Luciana Lasry Benchimol²; \\ Marilia Barbosa Chiavegato²; Luiz Antonio dos Santos Dias ${ }^{3}$; Carlos Augusto Colombo ${ }^{2}$ \\ ${ }^{1}$ IAC - Centro de Grãos e Fibras, C.P. 28 - 13001-970 - Campinas, SP - Brasil. \\ ${ }_{3}^{2}$ IAC - Centro de Recursos Genéticos Vegetais. \\ UFV/BIOAGRO - Depto. de Biologia Geral - 36571-000 - Viçosa, MG - Brasil. \\ *Corresponding author <carbonel@iac.sp.gov.br>
}

ABSTRACT: Germplasm banks store genotype samples, improved varieties, landraces and wild species, all generically denominated accessions. The importance of characterizing germplasm banks is based on the identification and knowledge of relevant traits for genetic improvement and ex situ germplasm conservation. Thus, the present study had as aim the evaluation of the genetic diversity among 220 accessions of a Brazilian common bean germplasm bank of the "Instituto Agronômico de Campinas" (IAC) by means of 23 morpho-agronomical descriptors and 19 RAPD loci. These accessions correspond to genotypes from the Andean and Middle American gene pool as well as from cultivars derived from common bean improvement programs. The Middle American accessions and the improved cultivars were clustered into one group, distinct from the one formed by the Andean accessions. In relation to the molecular data, $47 \%$ of the genetic similarity was detected among the Middle American accessions, and similar results were observed for the improved cultivars (50\%). The Andean accessions revealed $60 \%$ of genetic similarity. The cluster constituted by the improved cultivars and the Middle American genotypes differed, basically, in tegument color. Both molecular and morpho-agronomical data sets were equally effective to quantify and organize the genetic diversity of common bean accessions. This information may be useful to direct crosses and for the proper organization of the IAC germplasm bank.

Key words: Phaseolus vulgaris, germplasm bank, botanical descriptors, multivariate analyses

\section{DIVERSIDADE GENÉTICA EM ACESSOS DE FEIJOEIRO AVALIADA POR MEIO DE DADOS MORFO-AGRONÔMICOS E DE RAPD}

RESUMO: Bancos de germoplasma guardam amostras de genótipos, variedades melhoradas, crioulas e espécies selvagens, todas genericamente denominadas acessos. A importância da caracterização de bancos de germoplasma reside na identificação e no conhecimento de características relevantes para o melhoramento genético e para conservação ex situ do germoplasma. Avaliou-se a diversidade genética entre 220 acessos de feijoeiro de um banco brasileiro de germoplasma de feijoeiro localizado no IAC (Instituto Agronômico, Campinas), por meio de 23 descritores morfo-agronômicos e 19 locos de RAPD. Os acessos correspondem a genótipos do pool gênico andino e mesoamericano e também por cultivares resultantes de programas de melhoramento de feijoeiro. Os acessos mesoamericanos e as cultivares melhoradas foram agrupados em um mesmo grupo, distintamente dos acessos andinos. Com base nos dados moleculares, $47 \%$ de similaridade genética foi detectada entre acessos mesoamericanos e resultados semelhantes foram observados para as cultivares melhoradas (50\%). Os andinos apresentaram $60 \%$ de similaridade genética. O cluster formado pelas cultivares melhoradas e genótipos mesoamericanos apresentou diferenças quanto à coloração do tegumento. Ambos os conjuntos de dados, moleculares e morfo-agronômicos, foram igualmente eficientes para quantificação e estruturação da diversidade genética de acessos de feijoeiro. Essas informações poderão ser utilizadas para orientação de cruzamentos e para a conservação adequada do banco de germoplasma de feijoeiro do IAC.

Palavras-chave: Phaseolus vulgaris, bancos de germoplasma, descritores botânicos, análises multivariadas 


\section{INTRODUCTION}

Common bean (Phaseolus vulgaris L.) is found in two main centers of origin in the American continent: the Middle American and the Andean centers (Harlan, 1975). The importance of common bean characterization is based on the identification and knowledge of the relevant traits for genetic improvement and ex-situ germplasm conservation. Furthermore, data derived from germplasm characterization allows the quantification and organization of the genetic diversity.

Many studies use botanical and/or molecular information to quantify the amount of genetic divergence present in common bean genotypes (Chiorato et al., 2005; Machado et al., 2002; Rodrigues et al., 2002). In these studies, most of the analyzed cultivars present high rates of genetic similarity, as they share common ancestors (Alzate-Marin et al., 2003; Beebe et al., 1995; 2000; 2001; Duarte et al., 1999). The major limitation of morpho-agronomical characterization is that this kind of evaluation often involves a high number of descriptors, many of which influenced by the environment, particularly those conditioned by many genes.

Molecular markers were introduced in the 90s and proved to be extremely useful for studies on genetic plant diversity evaluation, since they are more informative and stable than morpho-agronomical descriptors (Cohen et al., 1991).

In the present study, 220 common bean accessions showing important agronomical traits for breeding belonging to germplasm bank of the "Instituto Agronômico de Campinas" (IAC), Campinas, Brazil were analyzed by means of morpho-agronomical as well as molecular loci (Random Amplified Polymorphism DNA i.e. RAPD), aiming to quantify and unveil the structure of their genetic diversity. Results between morpho-agronomical and molecular evaluations were correlated in order to identify possible effectiveness between these two methods.

\section{MATERIAL AND METHODS}

\section{Plant material}

The common bean germplasm bank of IAC contains 2,100 accessions of which 220 were sampled for a comparative analysis concerning genetic diversity, highlighted by morpho-agronomical descriptors and molecular markers. The sampling criterion was based on traits of economical importance for the genetic improvement of the crop. The selected accessions were from Andean (55) and Middle American (116) origins, besides improved cultivars (49) recommended for cultivation (Table 1).

\section{Morpho-agronomical analyses}

Twenty-three descriptors relative to plant, pod and seed, and the reaction to the physiological races 31, 65 and 89 of the anthracnose pathogen [Colletotrichum lindemuthianum (Sacc. \& Magn.) Scrib.] were used in the evaluation. The accessions were characterized during two consecutive years in Espírito Santo do Pinhal, in the São Paulo state, Brazil ( $46^{\circ} 45^{\prime} \mathrm{W}-22^{\circ} 04^{\prime} \mathrm{S}-680 \mathrm{~m}$ altitude). The accessions were sown in $3 \mathrm{~m}$ long rows, spaced $0.50 \mathrm{~m}$ apart, without replications, in order to multiply the seeds and evaluate the descriptors. The quantification of the genetic divergence among the accessions was made through multivariate analysis such as principal components and Euclidian distance. Bidimensional graphs were obtained by the principal components analysis. All morpho-agronomical analyses were performed by using the software Genes (Cruz, 2001).

\section{Molecular analyses}

Total genomic DNA was extracted from young leaf tissues ground in liquid nitrogen using MATAB (mixed alkyltrimethylammonium bromide) detergent. Polimerase Chain Reactions (PCR) were achieved in a final volume of $15 \mu \mathrm{L}$, containing $0.4 \mathrm{mM}$ primer, $10 \mathrm{mM}$ Tris- $\mathrm{HCl}$ (pH 8.3), $50 \mathrm{mM} \mathrm{KCl,} 2 \mathrm{mM} \mathrm{MgCL}$, $40 \mathrm{ng}$ DNA, $100 \mu \mathrm{M}$ of each deoxyribonucleotide (dNTP) and 1.0 unit of Taq DNA polymerase (Invitrogen). Amplifications were obtained in a thermocycler (PTC-100 MJ Research) programmed as follows: $95^{\circ} \mathrm{C}$ during $4 \mathrm{~min}$, followed by 43 cycles of 1 minute at $95^{\circ} \mathrm{C}, 1$ minute at $35^{\circ} \mathrm{C}$ and 1.5 minute at $72^{\circ} \mathrm{C}$, and a final extension of $72^{\circ} \mathrm{C}$, during $7 \mathrm{~min}$. Nineteen random primers (Qiagen-Operon) were adopted to analyze the accessions under study. RAPD loci were evaluated concerning the presence (1) or absence $(0)$ of the bands in order to establish a doubleinput matrix (bands $\times$ accessions). Then, the genetic similarity index among accessions was calculated by the Jaccard similarity coefficient, which was thereafter used for the analysis of the principal coordinates (biplot). Genetic similarity matrixes, established by the morpho-agronomical and molecular data were correlated (Mantel, 1967). Molecular data analyses and the Mantel correlations were processed using the NTSYS software (Rohlf, 2000).

\section{RESULTS AND DISCUSSION}

The 19 RAPD primers generated 201 loci of which 139 (67.16\%) were polymorphic (i.e. 7.1 bands per primer on average). The RAPD patterns from Middle American and Andean accessions, and improved cultivars produced variations (Figure 1). The maxi- 
Table 1 - Accession numbers, derived countries, origin centers, spectrum of reaction to anthracnose races 31, 65 and 89, seed sizes and tegument color for the 220 accessions of the IAC common bean germplasm bank.

\begin{tabular}{|c|c|c|c|c|c|c|c|c|c|c|c|c|c|c|c|c|c|c|c|}
\hline \multirow{2}{*}{ Countries } & \multirow{2}{*}{$\begin{array}{l}\text { Number of } \\
\text { accessions }\end{array}$} & \multicolumn{3}{|c|}{ Origin } & \multicolumn{3}{|c|}{$\begin{array}{l}\text { Anthracnose } \\
\text { Reaction }^{1}\end{array}$} & \multicolumn{3}{|c|}{ Seed Size ${ }^{2}$} & \multicolumn{9}{|c|}{ Tegument Color ${ }^{3}$} \\
\hline & & MA & $\mathrm{A}$ & IC & $\mathrm{R}$ & $\mathrm{S}$ & I & Small & Medium & Large & Yellow & White & Carioca & Cream & Mulatinho & Black & Speckled & Pink & Red \\
\hline Argentina & 3 & 2 & 1 & 0 & 0 & 2 & 1 & 1 & 2 & 0 & 0 & 1 & 1 & 1 & 0 & 0 & 0 & 0 & 0 \\
\hline Brazil & 106 & 65 & 22 & 19 & 21 & 46 & 39 & 76 & 24 & 6 & 1 & 2 & 14 & 18 & 5 & 33 & 16 & 7 & 10 \\
\hline Chile & 2 & 1 & 1 & 0 & 1 & 0 & 1 & 1 & 1 & 0 & 0 & 1 & 0 & 0 & 0 & 1 & 0 & 0 & 0 \\
\hline CIAT* & 44 & 18 & 13 & 13 & 14 & 13 & 17 & 29 & 13 & 2 & 1 & 1 & 6 & 6 & 2 & 14 & 11 & 0 & 3 \\
\hline Colombia** & 8 & 3 & 5 & 0 & 0 & 3 & 5 & 3 & 4 & 1 & 1 & 0 & 0 & 0 & 0 & 1 & 5 & 0 & 1 \\
\hline Costa Rica & 6 & 3 & 0 & 3 & 0 & 3 & 3 & 6 & 0 & 0 & 0 & 0 & 0 & 0 & 0 & 6 & 0 & 0 & 0 \\
\hline El Salvador & 1 & 0 & 0 & 1 & 0 & 1 & 0 & 1 & 0 & 0 & 0 & 0 & 0 & 0 & 0 & 1 & 0 & 0 & 0 \\
\hline Ecuador & 1 & 1 & 0 & 0 & 0 & 1 & 0 & 1 & 0 & 0 & 0 & 0 & 0 & 0 & 0 & 0 & 0 & 0 & 1 \\
\hline France & 1 & 0 & 1 & 0 & 0 & 1 & 0 & 0 & 1 & 0 & 0 & 0 & 0 & 0 & 0 & 0 & 1 & 0 & 0 \\
\hline Guatemala & 3 & 2 & 0 & 1 & 0 & 2 & 1 & 3 & 0 & 0 & 0 & 0 & 0 & 0 & 0 & 2 & 0 & 0 & 1 \\
\hline Honduras & 1 & 1 & 0 & 0 & 0 & 1 & 0 & 1 & 0 & 0 & 0 & 0 & 0 & 0 & 0 & 0 & 0 & 0 & 1 \\
\hline Mexico & 24 & 10 & 3 & 11 & 8 & 9 & 7 & 15 & 8 & 1 & 1 & 0 & 2 & 4 & 0 & 13 & 2 & 1 & 1 \\
\hline Holland & 1 & 0 & 1 & 0 & 0 & 1 & 0 & 1 & 0 & 0 & 0 & 1 & 0 & 0 & 0 & 0 & 0 & 0 & 0 \\
\hline Panama & 1 & 1 & 0 & 0 & 0 & 1 & 0 & 1 & 0 & 0 & 0 & 1 & 0 & 0 & 0 & 0 & 0 & 0 & 0 \\
\hline Peru & 2 & 1 & 1 & 0 & 2 & 0 & 0 & 1 & 0 & 1 & 0 & 0 & 0 & 1 & 0 & 1 & 0 & 0 & 0 \\
\hline $\begin{array}{l}\text { Dominican } \\
\text { Rep. }\end{array}$ & 2 & 0 & 2 & 0 & 2 & 0 & 0 & 1 & 1 & 0 & 0 & 0 & 0 & 0 & 0 & 0 & 2 & 0 & 0 \\
\hline Turkey & 1 & 1 & 0 & 0 & 0 & 1 & 0 & 1 & 0 & 0 & 0 & 0 & 0 & 0 & 1 & 0 & 0 & 0 & 0 \\
\hline United States & 10 & 4 & 5 & 1 & 2 & 4 & 4 & 4 & 3 & 3 & 0 & 2 & 0 & 1 & 0 & 3 & 0 & 0 & 4 \\
\hline Venezuela & 3 & 3 & 0 & 0 & 0 & 2 & 1 & 3 & 0 & 0 & 0 & 0 & 0 & 1 & 0 & 2 & 0 & 0 & 0 \\
\hline Total & 220 & 116 & 55 & 49 & 50 & 91 & 79 & 149 & 57 & 14 & 4 & 9 & 23 & 32 & 8 & 77 & 37 & 8 & 22 \\
\hline
\end{tabular}

MA: Middle American; A: Andean; IC: Improved Cultivars; R: Resistant of three races of anthracnose: 31, 65 and 89; S: Susceptible of three races of anthracnose: 31, 65 and 89; I: Intermediate resistance to at least one or two races of anthracnose:31, 65 and 89.

* International Center for Tropical Agriculture - Colombia. **Instituto Colombiano Agropecuario - ICA - Colombia. ${ }^{1}$ Number of accessions resistant or susceptible of anthracnose. ${ }^{2}$ Seed size evaluated toward with the mass of one hundred seeds: Small: 10 to 20 grammas; Medium: 21 to 40 grammas; Large: Up to 40 grammas. ${ }^{3}$ Number of accessions to each class of tegument color.

mum, minimum and intermediate values of molecular similarity based on RAPD data were $0.82,0.13$ and 0.54 , respectively, versus $0.73,0.11$ and 0.44 obtained by morpho-agronomical data. The 23 morphoagronomical descriptors revealed a greater genetic divergence than the 139 RAPD loci. This is probably due to the higher number of genes involved in the expression of the phenotypic traits and also because of the environmental influence conditioning phenotypic expression. Although a small number of RAPD loci were used here, the superior average similarity found within Middle American cultivars was consistent with other reports (Duarte et al., 1999; Emygdio et al., 2003). Indeed, the molecular clustering pattern is in agreement with the expected intrinsic genomic variability of our data. Therefore, RAPD markers were suitable for genotyping and clustering Middle American and
Andean cultivars, despite their random nature and the small number of loci evaluated.

The principal coordinate method based on the molecular similarity matrix discriminated Andean accessions from the Middle American. The improved cultivars were grouped together with Middle American accessions (Figure 2). Principal component analysis used for morpho-agronomical data showed similar results to those produced by principal coordinate analysis using molecular data. The accession dispersion in the display formed by the first two components showed how the Andean common beans grouped distinctly from the Middle American and from the improved cultivars. Once again, most of them clustered with Middle American accessions (Figure 3).

The first two principal components produced with morpho-agronomical data explained $32.3 \%$ of the 

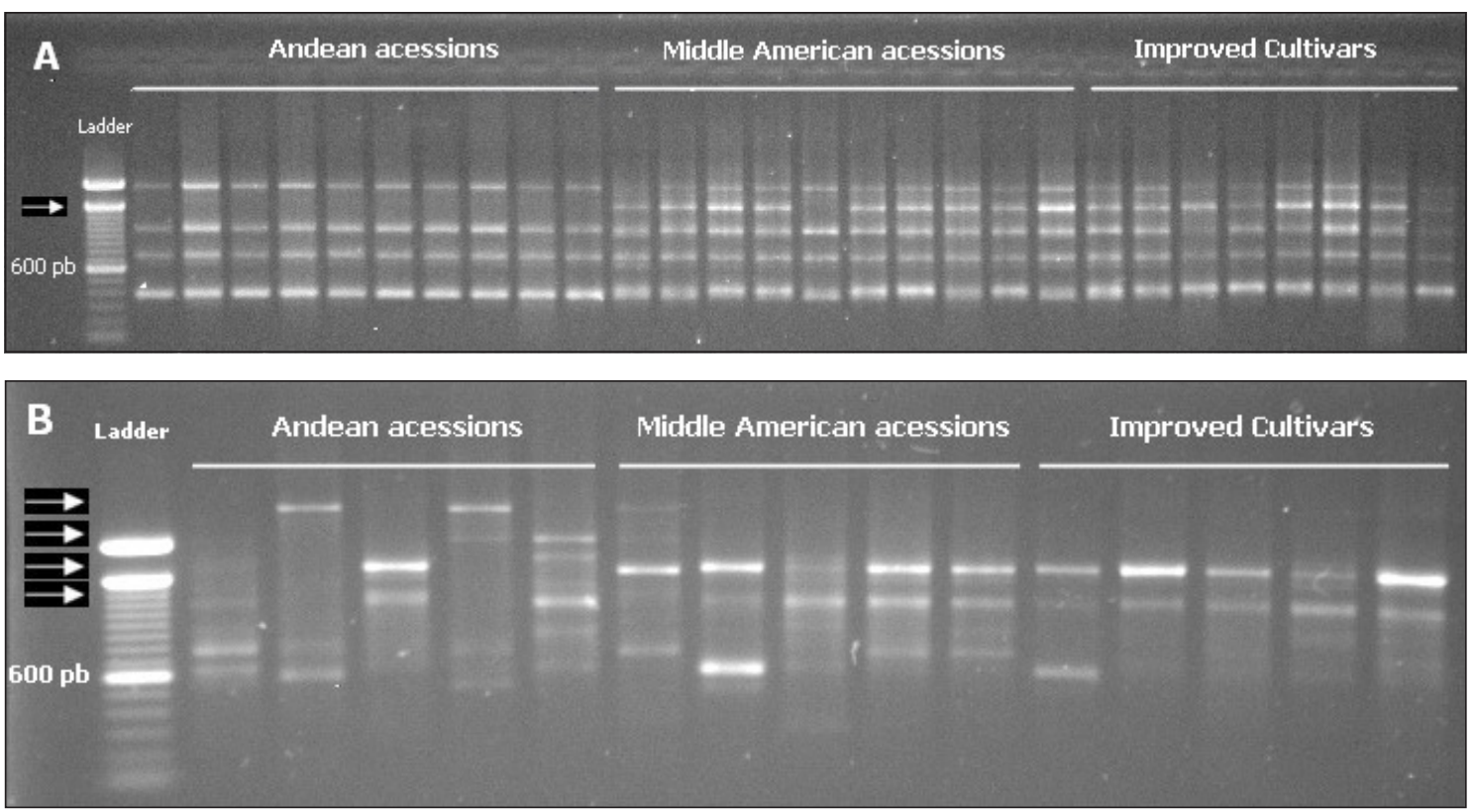

Figure 1 - Ethidium bromide stained electrophoretic profile of RAPD markers obtained for Middle American and Andean accessions and improved cultivars of common beans. The arrows show the variation in the RAPD patterns produced with OPA18 (A) and OPI16 (B) primers.

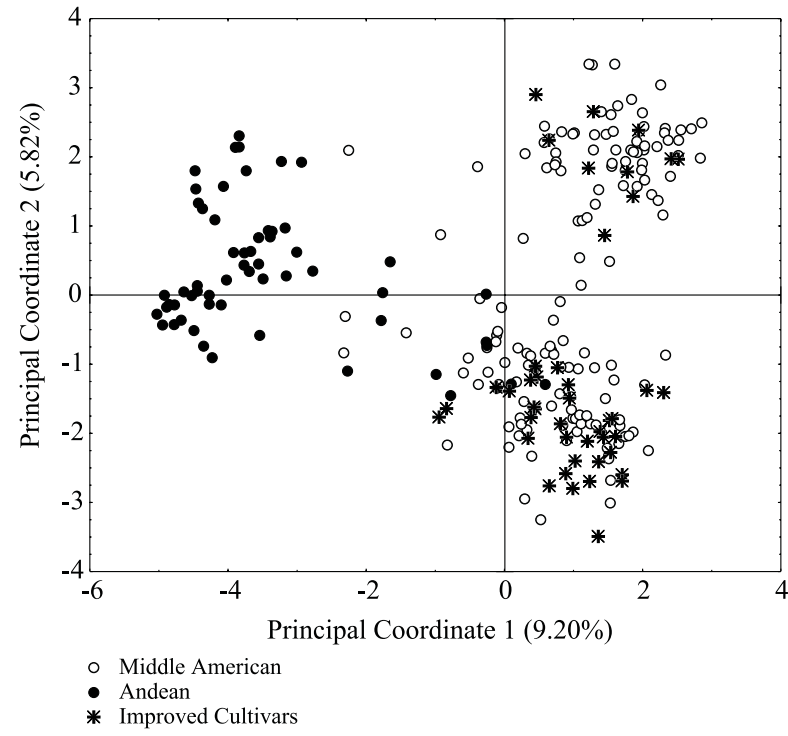

Figure 2 - Biplot of principal coordinates related to 220 accessions of the IAC common bean germplasm bank, based on the genetic similarity matrix (Jaccard) calculated for 139 RAPD bands.

total variation. In the same way, $17.7 \%$ of the total variation was explained by the first two principal coordinates generated by molecular data (Figures 1 and 2). In the first case, the descriptors that influenced the first principal components were mostly the mass of a thousand seeds and the seed size, which together explained $46 \%$ of the total variation for the morpho-agronomic genetic divergences obtained when using the Euclidian distance (Table 2).

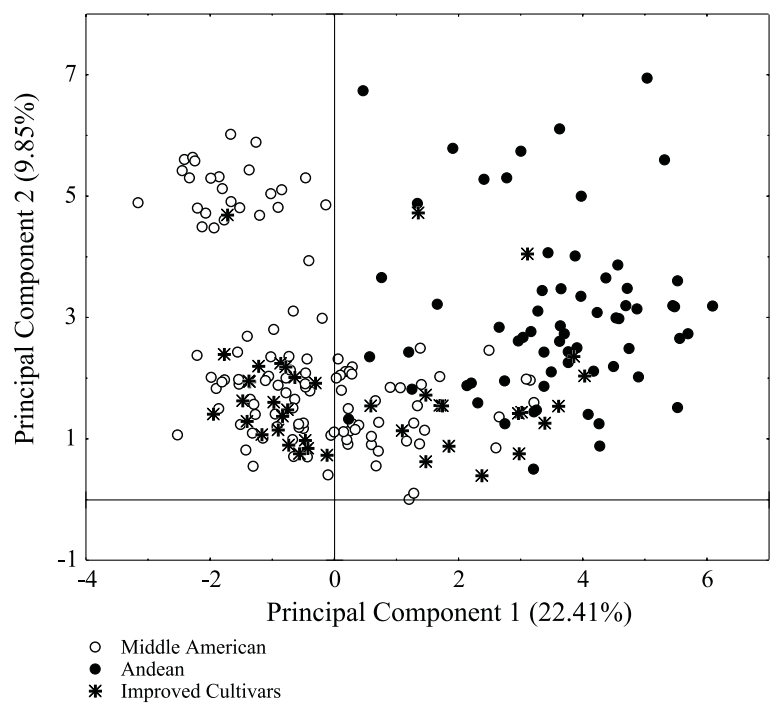

Figure 3 - Biplot of principal components related to 220 accessions of the IAC common bean germplasm bank, evaluated for 23 morpho-agronomical descriptors (plant, pod and seed) and reactions to the anthracnose pathogen (C. lindemuthianum).

The descriptors that influenced the accessions on the second component were plant height, primary and secondary grain color, explaining $29 \%$ of the total variation of the Euclidian dissimilarity analysis. Singh et al. (1991) evaluated 306 common bean genotypes and found similar results to these here obtained in what concerns the separation of Middle American from Andean accessions. The authors used principal component analysis and seed size, width and weight of 
1000 seeds as descriptors, and found that they were the most important determinants for genotype separation.

In relation to morpho-agronomical and molecular clustering, Andean accessions had a slight greater dispersion than that of the Mesoamericans (Figure 3). The major hypothesis that could explain such results might be associated with how this collection was built. Due to the preference to gather genotypes similiar to "carioca" and black-tegument types, and as a result of the selection practices towards a Middle American resemblance, the Middle American accessions were

Table 2 - Relative contribution of 23 morpho-agronomical descriptors used for the analysis of genetic divergence in 220 common bean accessions based on Euclidian distance analysis.

\begin{tabular}{lc}
\hline Morpho-agronomical descriptors & Relative contribution \% \\
\hline mass of a thousand seeds & 29.82 \\
seed size & 16.94 \\
plant height & 16.83 \\
secondary seed color & 7.22 \\
primary seed color & 5.81 \\
seed gloss & 5.70 \\
color of the seed halo & 3.07 \\
pod length & 2.07 \\
growth habit & 1.69 \\
hue of the secondary pod color & 1.61 \\
seed shape & 1.22 \\
reaction to race 65 & 1.20 \\
pod profile & 1.19 \\
reaction to race 31 & 1.18 \\
reaction to race 89 & 1.09 \\
flower color & 1.02 \\
number of seeds per pod & 0.86 \\
seed profile & 0.66 \\
format of bracteole & 0.24 \\
number of seed colors & 0.23 \\
secondary pod color & 0.18 \\
primary pod color & 0.15 \\
pod length & 0.03 \\
\hline
\end{tabular}

phenotypically less divergent. On the other hand, no commercial interest was devoted to Andean accessions until sometime ago. Probably, this fact caused their casual entry into the germplasm bank.

Regarding molecular-data clustering (Figure 2), the Andean group diversity was smaller than that of Middle America. The maximum, minimum and intermediate genetic similarity values were obtained within each common bean group based on the 139 RAPD loci (Table 3). Data analysis showed that the diversity among Middle American accessions was greater than the one found among Andean accessions. Two hypotheses might be considered: the first one is related to the number of the samples of each group that was unequal. Most of the accessions from the IAC common bean germplasm bank were represented by the Middle American ones. Certainly, the unbalanced proportion made the Andean accessions to be less divergent, as the information based on molecular data is less affected by the environment. Morpho-agronomic information are influenced by environmental factors and this contributed for a greater dispersion of the Andean accessions (Figure 3); a second hypothesis could be sustained by the literature, according to which thed Andean common bean genotypes presented less variability (Emygdio et al., 2003; Beebe et al., 2001; Duarte et al., 1999; Vasconcelos et al., 1996). In this case, it would be worthless to raise the Andean proportion. Despite the lower number of Andean accessions, important characteristics were observed such as grain color, plant type and resistance to the anthracnose pathogen.

Improved plant clustering with both data sets were grouped together with Middle American accessions. As already mentioned, this result derived from the selection processes conducted in breeding programs. Regarding molecular data clustering (Figure 2), the group constituted of improved cultivars with Middle American accessions was better solved than the one obtained with morpho-agronomic data, which was much more scattered. This result reinforces the hypothesis that the majority of the crosses under common bean breeding programs used Middle American progenitors for obtaining superior lines.

Table 3 - Maximal, minimal and intermediate values of genetic similarity obtained within each group of common beans, based on139 RAPD bands.

\begin{tabular}{lccc}
\hline \multirow{2}{*}{ Genetic Similarity } & \multicolumn{3}{c}{ Groups } \\
\cline { 2 - 4 } & Middle American (116 accessions) & ImprovedCultivars (49 accessions) & Andean (55 accessions) \\
\hline maximum & 0.82259 & 0.7561 & 0.70652 \\
intermediate & 0.47627 & 0.50487 & 0.60149 \\
minimum & 0.13483 & 0.20732 & 0.22989 \\
\hline
\end{tabular}


The variability of the genetic pools must be strengthened. Since the choice of the accessions was based in accordance to the IAC breeding program needs, the observed diversity should not be extrapolated to represent the natural diversity of both genetic pools (Andean and Middle American). Based on the dispersion of the accessions in the morpho-agronomical and molecular biplots, is important to remember that Andean- and Middle American-genotype crosses often do not result in a high yield capacity, as suggested by Singh et al. (1989) and Singh (1995). The recombination of these two centers of origin is indicated when focusing the introgression of economically important genes from the Andean into the Middle American group.

In the IAC common bean breeding program, every cultivar recommended for harvesting should hold resistance against the anthracnose races 31, 65 and 89 [Colletotrichum lindemuthianum (Sacc. \& Magn.) Scrib.]. As reported by Chiorato et al. (2006), Middle American genotypes were more susceptible to these three races than Andean genotypes and therefore we could suppose that a co-evolutionary process might have occurred between plant and pathogen in relation to common bean anthracnose. Therefore, crossings between Andean and Middle American genotypes are strongly recommended for transference of Andean origin resistance genes to the Middle American group. Indeed, recombination between divergent accessions from Andean and Middle American origins should be explored for pyramidation of resistance genes, especially in studies focusing the extension of the spectrum of resistance of a cultivar (Young \& Kelly, 1997).

According to the accession dispersion (Figures 2 and 3), we so far recommend the recombination of Middle American accessions and improved groups, with lowest genetic similarities, without losing track of the most important agronomical and commercial traits. Focusing the broadening of the genetic base for gathering major anthracnose resistance and angular leaf spot resistance, recombination of Andean accessions with Middle American ones should be a priority.

Among the common bean genetic improvement goals, the development of cultivars with carioca and black teguments has been a priority and in view of this, subdivision in two main groups occurred based on tegument type: improved cultivars and Middle American accessions separated from the Andean accessions (Figure 4). Tegument type is represented in the analysis by the primary and secondary seed color descriptors. Together, they explained $13 \%$ of the total variation, indicating the importance of these descriptors in the discrimination of the Middle American and

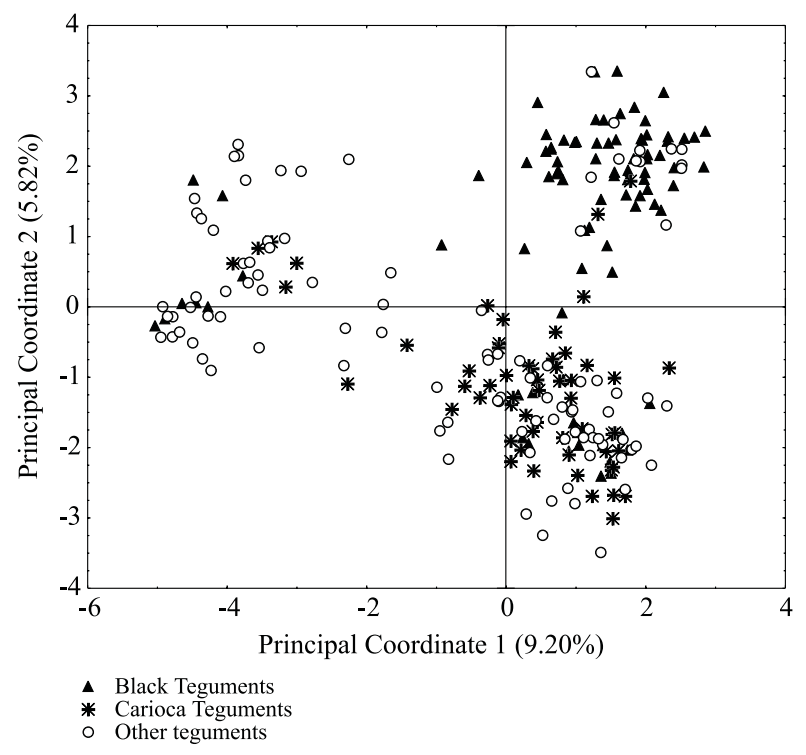

Figure 4 - Biplot of principal coordinates related to 220 accessions of the IAC common bean germplasm bank in relation to the tegument color, based on the genetic similarity matrix of Jaccard, calculated for 139 RAPD bands.

improved cultivars from Andean accessions (Table 2). Likewise, the separation of accessions by tegument color was observed through the use of molecular data (Figure 4), underlining how important and practical molecular markers are for characterization studies of the common bean germplasm. This separation of accessions based on tegument color is supported by Duarte et al. (1999) and Alzate-Marin et al. (2003).

In relation to the descriptors that influence the accessions on the first principal components, the seed size and mass of a thousand seeds explained $46 \%$ of the total variation. This information indicates that one of the principal characteristics that separate the two origin centers is related to seed descriptors. Andean accessions present greater seeds than the Middle American accessions, and this descriptor, together with grain color, were the most important ones for accession separation.

Plant height explained alone $16 \%$ of the total variation. This result was intimately correlated to plant growing habit. Indeed, plants with growing habit type I are smaller than those with growth habit type II and III. Andean accessions generally present growth habit type I, while Mesoamericans have determinant growth habits type II and III and this can be used as a characteristic for group separation.

The matrixes of genetic similarity obtained for the data generated by morpho-agronomical and molecular descriptors were correlated one to each other in order to establish a correspondence among them. Despite an apparent similarity in the genetic structure of the analyzed accessions using these two datasets, 
Mantel's correlation with 10,000 permutations was relatively low, although being highly significant $(r=0.33, P<0.01)$. Similar analyses of common beans were performed by Duarte et al. (1999), who had also associated morphological data with RAPD markers. Nevertheless, the authors found no correlation.

In conclusion, common bean accessions have important genetic variability, with its structures in concordance to the origin center of the species, as well as grain type. Besides, the accessions from the Middle American center showed greater variability than those from the Andean center. The molecular profile obtained with the 19 RAPD primers presented a smaller genetic diversity than the morpho-agronomical descriptors, although both datasets highlighted a similar genetic structure for the studied material, as corroborated by the significant correlation observed between the respective matrixes of genetic similarities. The molecular and morpho-agronomical descriptors should be used together in studies of germplasm diversity and characterization of the common bean, contributing to the reliability of results and to proper understand accessions' relationships.

\section{REFERENCES}

ALZATE-MARIN, A.L.; COSTA, M.R.; SARTORATO, A.; PELOSO, M.J.; BARROS, E.G.; MOREIRA, M.A. Genetic variability and pedigree analysis of Brazilian common bean elite genotypes. Scientia Agricola, v.60, p.283-290, 2003.

BEEBE, S.; OCHOA, I.; SKROACK, P.; NIENHUIS, J.; TIVANG, J. Genetic diversity among common bean breeding lines developed for Central America. Crop Science, v.35, p.1178-1183, 1995.

BEEBE, S.; SKROCH, P.W.; TOHME, J.; DUQUE, M.C.; PEDRAZA, F.; NIENHUIS, J. Structure of genetic diversity among common bean landraces of Middle American origin based on correspondence analysis of RAPD. Crop Science, v.40, p.264-273, 2000.

BEEBE, S.; RENGIFO, J.; GAITAN, E.; DUQUE, M.C.; TOHME, J. Diversity and origin of landraces of common bean. Crop Science, v.41, p.854-862, 2001.

CHIORATO, A.F.; CARBONELL, S.A.M.; RAMOS, R.R.; ITO, M.F.; COLOMBO, C.A. Co-evolução entre raças fisiológica de Colletotrichum lindemuthianum e feijoeiro. Bragantia, v.65, p.381-388, 2006.

CHIORATO, A.F.; CARBONELL, S.A.M.; COLOMBO, C.A.; DIAS, L.A.S.; ITO, M.F. Genetic diversity of common bens accessions in the germplasm bank of the Instituto Agronômico - IAC. Crop Breeding and Applied Biotechnology, v.5, p.1-9, 2005.
COHEN, J.I.; ALCORN, J.B.; POTTER, C.S. Utilization and conservation of genetic resources: international projects for sustainable agriculture. Economic Botany, v.45, p.190-199, 1991.

CRUZ, C.D. Programa GENES versão Windows: aplicativo computacional em genética e estatística. Viçosa: Editora UFV, 2001. 648p.

DUARTE, J.M.; SANTOS, J.B.; MELO, L.C. Genetic divergence among common bean cultivars from different races based on RAPD markers. Genetics and Molecular Biology, v.22, p.419-426, 1999.

EMYGDIO, B.M.; ANTUNES, I.F.; NEDEL, J.L.; CHOER, E. Diversidade genética em cultivares locais e comerciais de feijoeiro baseado em marcadores RAPD. Pesquisa Agropecuária Brasileira, v.38, p.1165-1171, 2003.

HARLAN, J.R. Geographic patterns of variation in some cultivated plants. Journal of Heredity, v.66, p.184-191, 1975.

MACHADO, C.F.; NUNES, G.H.S.; FERREIRA, D.F.; SANTOS, J.S. Divergência genética entre genótipos de feijoeiro a partir de técnicas multivariadas. Ciência Rural, v.32, p.251-258, 2002.

MANTEL, N. The detection of disease clustering and a generalized regression approach. Cancer Resources, v.27, p.209-220, 1967.

RODRIGUES, L.S.; ANTUNES, I.F.; TEIXEIRA, M.G.; SILVA, J.B. Divergência genética entre cultivares locais e cultivares melhoradas de feijão. Pesquisa Agropecuária Brasileira, v.37, p.1285-1294, 2002.

ROHLF, F.J. NTSys-pc: Numerical taxonomy and multivariate analysis system. New York: Exeter Software, 2000.

SINGH, S.P. Selection for seed yield in Middle American versus Andean $\mathrm{x}$ Middle American interracial common-bean populations. Plant Breeding, v.114, p.269-271, 1995.

SINGH, S.P.; CAJIAO, C.; GUTIÉRREZ, J.A.; GARCIA, J.; PASTOR-CORRALES, M.A.; MORALES, F.J. Selection for seed yield in inter-gene pool crosses of common bean. Crop Science, v.29, p.1126-1131, 1989.

SINGH, S.P.; GUTIÉRREZ, J.A.; MOLINA, A.; URREA, C.; GEPTS, P. Genetic diversity in cultivated common beans: II. Markers based analysis of morphological and agronomic traits. Crop Science, v.31, p.23-29, 1991.

VASCONCELOS, M.J.V.; BARROS, E.G.; MOREIRA, M.A.; VIEIRA, C. Genetic diversity of the common bean Phaseolus vulgaris L. determined by DNA-based molecular markers. Brazilian Journal of Genetics, v.19, p.447-451, 1996.

YOUNG, R.; KELLY J.D. RAPD markers linked to three major anthracnose resistance gene in common bean. Crop Science, v.37, p.940-946, 1997.

Received January 20, 2006

Accepted March 23, 2007 